\title{
THE PERFORMANCE AND EXTRACELLULAR POLYMERIC SUBSTANCES VARIATIONS OF AN ANAEROBIC-ANOXIC-OXIC WASTEWATER TREATMENT PROCESS SUBJECTED TO ORGANIC CARBON AND AMMONIA NITROGEN SHOCK LOADINGS
}

\author{
ZHANG, L. H. ${ }^{1 *}-$ ZHANG, M. S. ${ }^{1}-$ GUO, J. B. ${ }^{2}-$ CHEN, Z. C. ${ }^{1}-$ LING, L. X. ${ }^{1}$ \\ ${ }^{1}$ School of Chemical Engineering, Northeast Electric Power University, 132012 Jilin, China \\ (phonelfax: +86-432-6480-6371) \\ ${ }^{2}$ School of Civil and Architecture Engineering, Northeast Electric Power University \\ 132012 Jilin, China \\ (phone/fax: +86-432-6480-6371) \\ *Corresponding author \\ e-mail:zhanglanhe@163.com
}

(Received 29 $9^{\text {th }}$ Jun 2018; accepted 22 ${ }^{\text {nd }}$ Aug 2018)

\begin{abstract}
Sudden changes in influent organic carbon (OC) and ammonia nitrogen (AN) concentrations were performed to evaluate the resistance of $\mathrm{A}^{2} \mathrm{O}$ process against shock loadings. The influent organic loading rate was increased from $11 \mathrm{gCOD} /(\mathrm{gMLSS} \cdot \mathrm{d})$ to $48 \mathrm{gCOD} /(\mathrm{gMLSS} \cdot \mathrm{d})$ with low $\mathrm{OC}$ shocking loading and to $125 \mathrm{~g} \mathrm{COD} /(\mathrm{gMLSS} \cdot \mathrm{d})$ with high OC shock loading. The influent $\mathrm{NH}_{4}{ }^{+}-\mathrm{N}$ was increased from $55 \mathrm{mg} / \mathrm{L}$ to $110 \mathrm{mg} / \mathrm{L}$ as $\mathrm{AN}$ shock loading. The results showed that the augmented OC concentration was beneficial for nitrogen removal and high AN concentration had slight influences on COD removal, but was detrimental to nitrogen removal in the $\mathrm{A}^{2} \mathrm{O}$ system. The performance of the $\mathrm{A}^{2} \mathrm{O}$ system restored rapidly from the shock loadings once the normal influent conditions were provided. The loosely bound extracellular polymeric substances (LB-EPS) and total extracellular polymeric substances (EPS) increased at the initial stage of shock loadings and then declined with the prolonged shock loading, whereas the tightly bound EPS (TB-EPS) experienced smaller variations. The SVI value varied in a similar trend with LB-EPS and total EPS and their low values indicated a good settleability of the activated sludge. In conclusion, the $\mathrm{A}^{2} \mathrm{O}$ process produced high-quality effluents once the shock loading ceased.
\end{abstract}

Keywords: activated sludge, denitrification rate, nitrification rate, flocculation, settleability, dissolved oxygen

Abbreviations: $A^{2}$ O: Anaerobic-anoxic-oxic, OLR: Organic loading rate, EPS: Extracellular polymeric substances, LB-EPS: Loosely bound EPS, TB-EPS: Tightly bound EPS, DO: Dissolved oxygen, ORP: Oxidation-reduction potential, COD: Chemical oxygen demand, BOD: Biochemical oxygen demand, MLSS: Mixed liquid suspended solids, $\mathrm{NH}_{4}{ }^{+} \mathrm{N}$ : Ammonia-nitrogen, $\mathrm{NO}_{2}{ }^{-} \mathrm{N}$ : Nitrite nitrogen, $\mathrm{NO}_{3}{ }^{-} \mathrm{N}$ : Nitrate nitrogen, TN: Total nitrogen, HRT: Hydraulic retention time, SVI: Sludge volume index

\section{Introduction}

Excessive nitrogen inflow from industrial and municipal wastewater is strictly controlled due to severe eutrophication and environmental pollution (Chang et al., 2006; Yang et al., 2008; Chen et al., 2011). A variety of nitrogen removal processes had been developed and extensive researches have been conducted on the nitrogen removal mechanisms. Over the past several decades, biological nitrification-denitrification processes have been widely applied for their cost-effective and eco-friendly features compared with chemical treatment methods (Guo et al., 2005; Bassin et al., 2012; Seifi 
and Fazaelipoor, 2012; Tanabene et al., 2018). The biological nitrogen removal processes developed include the five-stage Bardenpho process, the University of Cape Town (UCT) process, the sequencing batch reactor (SBR) and the anaerobic-anoxicoxic $\left(\mathrm{A}^{2} \mathrm{O}\right)$ process, etc. (Peng et al., 2006; Chen et al., 2011). Based on these biological processes, strategies for realizing short-cut nitrification denitrification, anaerobic ammonium oxidation (ANAMMOX) and simultaneous nitrification and denitrification (SND) were widely investigated in order to lower the construction investment and energy requirements (Zhang et al., 2008; Walters et al., 2009; Park et al., 2010; Yong et al., 2017). The most commonly used process was the anaerobic-anoxic-oxic process $\left(\mathrm{A}^{2} \mathrm{O}\right.$ process $)$ due to its convenient operation and management and high biological nitrogen removal efficiency (Pai et al., 2010). The $\mathrm{A}^{2} \mathrm{O}$ process is a sludge suspended growth system incorporating separate anaerobic, anoxic and aerobic stages in sequence to satisfy the requirement of oxygen in the nitrification and the absence of oxygen in the denitrification. Under aerobic stages, $\mathrm{NH}_{4}{ }^{+}-\mathrm{N}$ was oxidized, first to $\mathrm{NO}_{2}{ }^{-} \mathrm{-N}$ and then, to $\mathrm{NO}_{3}{ }^{-}-\mathrm{N}$. Furthermore, the residual $\mathrm{NO}_{2}{ }^{-} \mathrm{N}$ and $\mathrm{NO}_{3}{ }^{-} \mathrm{N}$ in the reflux were then denitrified to gaseous nitrogen compounds under the anaerobic and anoxic conditions.

The nitrogen removal performances of the $\mathrm{A}^{2} \mathrm{O}$ process under various environmental conditions were widely investigated in the previous literature. Ma et al. (2006) indicated that the nitrogen removal efficiency increased when the dissolved oxygen (DO) concentration in the aerobic stage rose from $2 \mathrm{mg} / \mathrm{L}$ to $3 \mathrm{mg} / \mathrm{L}$, and almost no improvement was observed when the DO was further enhanced to $4 \mathrm{mg} / \mathrm{L}$. The reflux ratio of the mixed liquid and carbon source type could also influence the performance of $\mathrm{A}^{2} \mathrm{O}$ process (Xu et al., 2009; Zhu et al., 2014). However, a very limited number of investigations were reported in terms of the performances of the $\mathrm{A}^{2} \mathrm{O}$ process under shock loadings. The sudden changes of influent constituents or shock loading could eventually destabilize the performance of the biological treatment system (Wang et al., 2006). As the biological systems were frequently under shock loadings as a result of wastewater quantity and quality fluctuations, it is necessary to understand the performance of the $\mathrm{A}^{2} \mathrm{O}$ process under shock loadings.

In the biological wastewater treatment reactors, the bio-flocculated microbial aggregates, known as activated sludge flocs, are the essential components of the process. It is, therefore, an undisputed fact that the physicochemical characteristics of activated sludge flocs play an important role in the performance of the process (Ye et al., 2011). Indeed, almost all the performances of the activated sludge process are related to or dependent on the physicochemical properties of the flocs, including flocculation, sludge settling and sludge dewatering. Extracellular polymeric substances (EPS) are one of the representative components of the flocs and are considered to have significant influences on the physicochemical properties of microbial aggregates, including structure, surface charge, flocculation, settling properties, dewatering properties, and adsorption ability (Sheng et al., 2008; Shou et al., 2018). They came from molecules in wastewater or from cell lyses, which consisted of various organic substances mainly including polysaccharides, proteins, and nucleic acid, etc. (Li et al., 2008). EPS in sludge flocs could be stratified into loosely bound EPS (LB-EPS) and tightly bound EPS (TB-EPS) based on the extraction methodology (Zhang and Wang, 2014). LB-EPS could diffuse into mixed liquid and had a loose structure at the outer layer of EPS. However, TB-EPS had a stable structure between LB-EPS and cell. And TB-EPS could be tightly combined with the cell surface and stick to the cell wall (Sheng et al., 2008). EPS are involved in the formation of microbial aggregates and are 
closely connected to their mass transfer, surface charge, adhesion ability, flocculation ability, settleability and stability (Sheng et al., 2010). The nature and content of EPS are sensitive to the operational and environmental conditions (Ye et al., 2011). However, few data were available concerning the effects of the organic loading rate (OLR) on the EPS. The resistant ability to shock loading and nitrogen removal properties can be comprehensively understood when the characterization of EPS was comprehended under different OLRs in the activated sludge of the $\mathrm{A}^{2} \mathrm{O}$ process.

The shock loadings were carried out by varying the influent sodium acetate as the carbon source and the influent ammonia chloride as the nitrogen source in synthetic municipal wastewater of the $\mathrm{A}^{2} \mathrm{O}$ process. The carbon and nitrogen removal efficiency were evaluated under organic carbon (OC) and ammonia nitrogen (AN) shock loadings. Meanwhile, the variations of EPS and sludge volume index (SVI) were also investigated under various levels of OC and AN shock loadings. The objective of this study is to investigate the ability of the $\mathrm{A}^{2} \mathrm{O}$ process to withstand the shock loadings that were applied to the reactors and to evaluate the corresponding characteristics of the activated sludge represented by EPS amount and SVI value. The results obtained in this study could provide guidance for the operation of the $\mathrm{A}^{2} \mathrm{O}$ process encountering shock loadings; for example, whether the system could survive the shock loadings without additional installations or measures should be performed to alleviate the passive influences of the shock loadings.

\section{Materials and methods}

\section{Operation of the reactor}

A bench-scale anaerobic-anoxic-oxic $\left(\mathrm{A}^{2} \mathrm{O}\right)$ reactor with a working volume of $60 \mathrm{~L}$ was used in this study (Fig. 1) and it was constructed refer to the reference (Zeng et al., 2010; Li et al., 2014; Zhang et al., 2017). A ${ }^{2}$ O reactor was operated from April 2016 to November 2017 in the waste treatment lab of Northeast Electric Power University, Jilin, China. There were eight zones in the reactor, separated by baffles to achieve anaerobic/anoxic and aerobic conditions. The first two zones were typically operated as anaerobic reactors, and the following two zones as anoxic reactors, while the remaining four as aerobic zones with separate aeration facilities. The raw wastewater and the recycled sludge flowed into the first zone of the anaerobic reactor and the mixed nitrate liquid was recycled from the last zone of the aerobic reactor to the first zone of the anoxic reactor. The flow rates of the influent, recycled sludge and nitrate recirculation were controlled together by peristaltic pump and regulating valve and the regulating valve was located at the outlet of the influent water tank. Internal recycle was the recycle of nitrification liquid to anoxic stage and external recycle was the recycle of sludge to anaerobic stage.

Recycle ratios of internal recycle and external recycle were $100 \%$ and $80 \%$, respectively, with an influent flow rate of $43.44 \mathrm{~L} / \mathrm{d}$. Stirrers provided the mixture of sludge in the anaerobic and anoxic zones and kept the biomass in suspension. Aeration was provided in each aerobic zone when the pressurized air passed through long stone diffusers. The diffusers used in the lab-scale $\mathrm{A}^{2} \mathrm{O}$ system were stone material with micro pores that could transfer the compressed air into the mixed liquid. The treated wastewater was settled in a vertical sedimentation basin with a total volume of $5 \mathrm{~L}$. The design and operational parameters of the $\mathrm{A}^{2} \mathrm{O}$ configuration are listed in Table 1. 


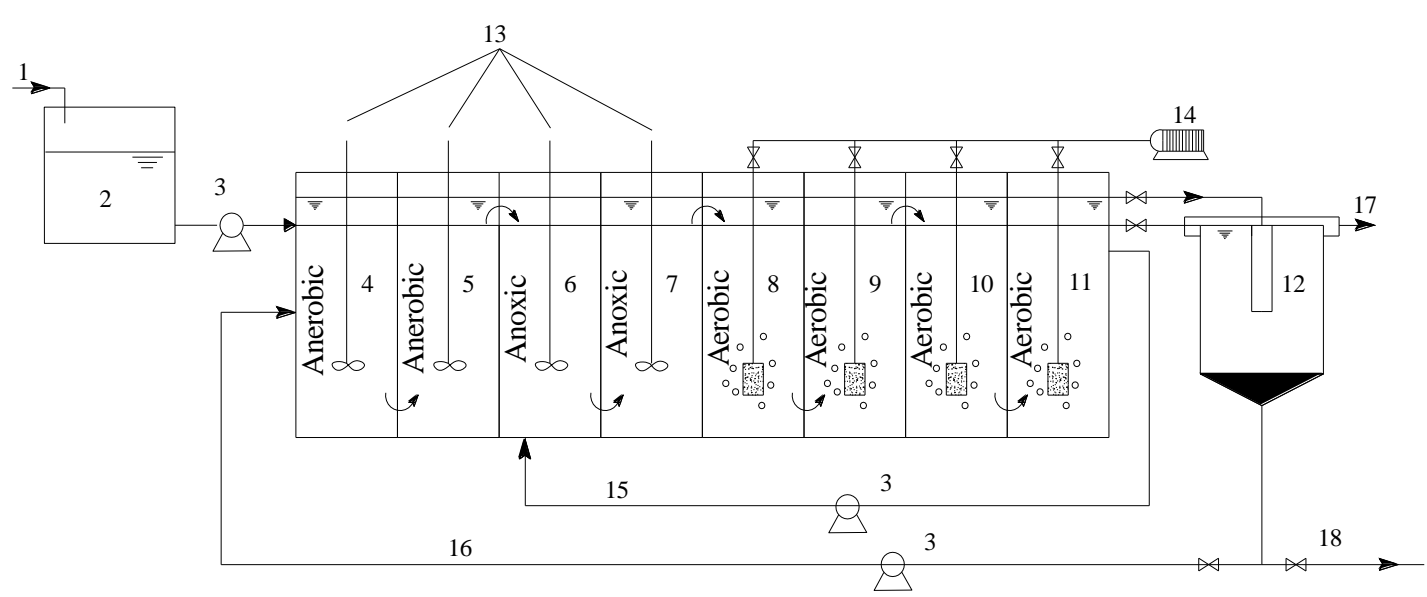

Figure 1. Schematic diagram of the $A^{2} O$ process. 1-Feed; 2-Tank; 3-Peristaltic pump; 4Anerobic 1; 5-Anerobic 2; 6-Anoxic 1; 7-Anoxic 2; 8-Aerobic 1; 9-Aerobic 2; 10-Aerobic 3; 11 Aerobic 4; 12-Settling tank; 13-Stirrer; 14-Air compressor; 15-Internal recycle; 16-Sludge recycle; 17-Effluent; 18-Excess sludge

Table 1. The design and operational parameters of $A^{2} O$ reactor

\begin{tabular}{|c|c|c|c|}
\hline \multicolumn{4}{|c|}{ Design parameters } \\
\hline Stage & Number & Volume (L) & HRT (h) \\
\hline Anaerobic zone & 2 & 15 & 4.34 \\
\hline Anoxic zone & 2 & 15 & 4.34 \\
\hline Aerobic zone & 4 & 30 & 8.70 \\
\hline Total & 8 & 60 & 17.38 \\
\hline Settler & 1 & 5 & 2.48 \\
\hline \multicolumn{4}{|c|}{ Operational parameters } \\
\hline \multicolumn{2}{|c|}{$\mathrm{Q}_{\text {Influent }}(\mathrm{L} / \mathrm{d})$} & \multicolumn{2}{|c|}{43.44} \\
\hline \multicolumn{2}{|c|}{ Internal recycling ratio $(\%)$} & \multicolumn{2}{|c|}{80} \\
\hline \multicolumn{2}{|c|}{ External recycling ratio (\%) } & \multicolumn{2}{|c|}{100} \\
\hline $\mathrm{DO}(\mathrm{mg} / \mathrm{L})$ & $\begin{array}{l}\text { Anoxic reactor } \\
\text { Oxic reactor }\end{array}$ & \multicolumn{2}{|c|}{$\begin{array}{l}\leq 1 \\
5-7\end{array}$} \\
\hline \multicolumn{2}{|c|}{ ORP in the anaerobic reactor } & \multicolumn{2}{|c|}{$\leq-100 \mathrm{mv}$} \\
\hline \multicolumn{2}{|c|}{$\mathrm{T}\left({ }^{\circ} \mathrm{C}\right)$} & \multicolumn{2}{|c|}{$15 \pm 2$} \\
\hline \multicolumn{2}{|c|}{$\mathrm{pH}$} & \multicolumn{2}{|c|}{$7.0-8.0$} \\
\hline \multicolumn{2}{|c|}{ MLSS (mg/L) } & \multicolumn{2}{|c|}{$1500 \pm 200$} \\
\hline
\end{tabular}

During the start-up period, the system was operated and fed with the synthetic wastewater with chemical oxygen demand (COD) of approximately $400 \mathrm{mg} / \mathrm{L}$ and $\mathrm{NH}_{4}{ }^{+}-\mathrm{N}$ of approximately $55 \mathrm{mg} / \mathrm{L}$. Samples were collected regularly from the influent and different zones of the reactor in order to analyze $\mathrm{NH}_{4}{ }^{+}-\mathrm{N}, \mathrm{NO}_{2}^{-}-\mathrm{N}, \mathrm{NO}_{3}^{-}-\mathrm{N}$, total nitrogen (TN), COD and mixed liquid suspended solids (MLSS), respectively. Temperature, DO, ORP and $\mathrm{pH}$ were measured online. After two-month operation, the removal efficiency of $\mathrm{COD}, \mathrm{NH}_{4}{ }^{+}-\mathrm{N}$ and $\mathrm{TN}$ were respectively higher than $95 \%, 95 \%$ and $85 \%$, which could indicate the successful start-up of the $\mathrm{A}^{2} \mathrm{O}$ system and 
achievement of the steady-state as the effluent water quality meet the Level I (B) criteria of the Discharge Standard of Pollutants for Municipal Wastewater Treatment Plant (GB18918-2002) of China. COD, $\mathrm{NH}_{4}{ }^{+}-\mathrm{N}$ and TN were lower than $60 \mathrm{mg} / \mathrm{L}, 15 \mathrm{mg} / \mathrm{L}$ and $20 \mathrm{mg} / \mathrm{L}$, respectively, in the Discharge Standard of Pollutants for Municipal Wastewater Treatment Plant (GB18918-2002). And then the operation of the $\mathrm{A}^{2} \mathrm{O}$ process was divided into four different phases to investigate the influences of the OC and AN shock loadings on the performance of the system and the variations of the EPS and SVI. The arrangement of the organic and nitrogen shock loading experiment was illustrated in Table 2.

Table 2. The arrangement of the shock loading experiments

\begin{tabular}{|c|c|c|}
\hline Operation & Influent conditions & Days \\
\hline $\begin{array}{c}\text { Phase I } \\
\text { (Normal operation) }\end{array}$ & $\begin{array}{l}\text { Organic loading rate of } 11 \mathrm{gCOD} /(\mathrm{gMLSS} \cdot \mathrm{d}) ; \\
\mathrm{NH}_{4}{ }^{+}-\mathrm{N} \text { concentration of } 55 \mathrm{mg} / \mathrm{L}\end{array}$ & $0-60$ \\
\hline $\begin{array}{c}\text { Phase II } \\
\text { (Low OC shock loading) }\end{array}$ & $\begin{array}{c}\text { Organic loading rate increased from } 11 \mathrm{gCOD} /(\mathrm{gMLSS} \cdot \mathrm{d}) \\
\text { (3 days) to } 48 \mathrm{gCOD} /(\mathrm{gMLSS} \cdot \mathrm{d})(7 \text { days }) \text { and then recovered to } \\
11 \mathrm{gCOD} /(\mathrm{gMLSS} \cdot \mathrm{d}) \text { influent }(5 \mathrm{days}) ; \\
\mathrm{NH}_{4}^{+}-\mathrm{N} \text { concentration of } 55 \mathrm{mg} / \mathrm{L}\end{array}$ & $61-75$ \\
\hline $\begin{array}{c}\text { Phase III } \\
\text { (High OC shock loading) }\end{array}$ & $\begin{array}{c}\text { Organic loading rate increased from } 11 \mathrm{gCOD} /(\mathrm{gMLSS} \cdot \mathrm{d}) \\
\text { (3 days) to } 125 \mathrm{gCOD} /(\mathrm{gMLSS} \cdot \mathrm{d})(7 \text { days }) \text { and then recovered to } \\
11 \mathrm{gCOD} /(\mathrm{gMLSS} \cdot \mathrm{d})(5 \mathrm{days}) ; \\
\mathrm{NH}_{4}^{+}-\mathrm{N} \text { concentration of } 55 \mathrm{mg} / \mathrm{L}\end{array}$ & $76-90$ \\
\hline $\begin{array}{c}\text { Phase IV } \\
\text { (High AN shock loading) }\end{array}$ & $\begin{array}{l}\text { Organic loading rate is } 11 \mathrm{gCOD} /(\mathrm{gMLSS} \cdot \mathrm{d}) \\
\mathrm{NH}_{4}^{+}-\mathrm{N} \text { concentration increased from } 55 \mathrm{mg} / \mathrm{L} \text { to } 110 \mathrm{mg} / \mathrm{L} \\
(10 \text { days }) \text { and then recovered to } 55 \mathrm{mg} / \mathrm{L}(10 \text { days })\end{array}$ & $91-110$ \\
\hline
\end{tabular}

\section{Synthetic wastewater and sludge}

The bench-scale $\mathrm{A}^{2} \mathrm{O}$ reactor was fed with synthetic wastewater when sodium acetate was used as carbon source. The synthetic wastewater was prepared as follows (per liter): $\mathrm{CH}_{3} \mathrm{COONa}, 0.48-4.8 \mathrm{~g} ; \mathrm{NH}_{4} \mathrm{Cl}, 0.2 \pm 0.02 \mathrm{~g} ; \mathrm{K}_{2} \mathrm{HPO}_{4}, 0.03 \mathrm{~g} ; \mathrm{MgSO}_{4} \cdot 7 \mathrm{H}_{2} \mathrm{O}$, $0.05 \mathrm{~g} ; \mathrm{CaCl}_{2} \cdot 2 \mathrm{H}_{2} \mathrm{O}, 0.01 \mathrm{~g}$. The $\mathrm{pH}$ was controlled at $7.0-8.0$ by adding $\mathrm{NaHCO}_{3}$ and $\mathrm{HCl}$ solution. Excess sludge, which collected from the secondary settling tank of a municipal wastewater plant located in Jilin, China, was used as inoculum. The major influent characteristics are shown in Table 3.

Table 3. The major characteristics of the influent

\begin{tabular}{c|c}
\hline Parameters (mg/L) & Min/Max \\
\hline $\mathrm{COD}$ & $360-4300$ \\
$\mathrm{NH}_{4}{ }^{-}-\mathrm{N}$ & $55-110$ \\
$\mathrm{NO}_{2}{ }^{-}-\mathrm{N}$ & $0-2$ \\
$\mathrm{NO}_{3}{ }^{-}-\mathrm{N}$ & 0 \\
$\mathrm{TN}$ & $53-59$ \\
\hline
\end{tabular}




\section{Analytical methods}

COD, BOD, MLSS, $\mathrm{NH}_{4}{ }^{+}-\mathrm{N}, \mathrm{NO}_{2}{ }^{-}-\mathrm{N}, \mathrm{NO}_{3}{ }^{-}-\mathrm{N}$ and $\mathrm{TN}$ were measured according to the Standard Methods for the Examination of Water and Wastewater (APHA, 1998). Temperature, $\mathrm{pH}$, ORP and DO were analyzed online with a WTW pH/ORP sensor (WTW, pH 3310) and a DO sensor (WTW, OXi340i). $50 \mathrm{~mL}$ of activated sludge collected from Aerobic 4 of the $\mathrm{A}^{2} \mathrm{O}$ reactor was used to analyze the EPS amount. The extraction and quantification of LB-EPS and TB-EPS were performed according to the protocol described by Liang et al. (2010).

\section{Results}

\section{The influences of $O C$ shock loading on COD removal performance}

Unexpected industrial wastewater was often discharged into the sewage and resulted in the high COD surge of the municipal wastewater treatment plant. In addition, the biological wastewater system often experienced higher pollutants surge when there was an equipment failure. In order to investigate the effects of high COD surge on the performance of the municipal wastewater treatment plant, high OLRs of $48 \mathrm{gCOD} /(\mathrm{gMLSS} \cdot \mathrm{d})$ and $125 \mathrm{gCOD} /(\mathrm{gMLSS} \cdot \mathrm{d})$ were applied.

The COD removal performances under OC shock loading were shown in Figure 2. The effluent COD was below $60 \mathrm{mg} / \mathrm{L}$ and more than $95 \%$ of COD was removed in the first 3 days when the influent OLR was elevated from $11 \mathrm{gCOD} /(\mathrm{gMLSS} \cdot \mathrm{d})$ to $48 \mathrm{gCOD} /(\mathrm{gMLSS} \cdot \mathrm{d})$. The effluent COD was higher than $100 \mathrm{mg} / \mathrm{L}$ when the low OC shock loading continued. An average of $95 \%$ COD removal efficiency was achieved though the effluent COD concentration was higher than $100 \mathrm{mg} / \mathrm{L}$, which indicated that the $\mathrm{A}^{2} \mathrm{O}$ system could remove more organic carbon at higher OLR. When the influent OLR returned to $11 \mathrm{gCOD} /(\mathrm{gMLSS} \cdot \mathrm{d})$ on the $71^{\text {th }}$ day, the effluent COD concentration was stable and below $30 \mathrm{mg} / \mathrm{L}$. It is suggested that the $\mathrm{A}^{2} \mathrm{O}$ process had strong resistant ability to low organic shock loading and the system could restore rapidly when the organic shock loading stopped.

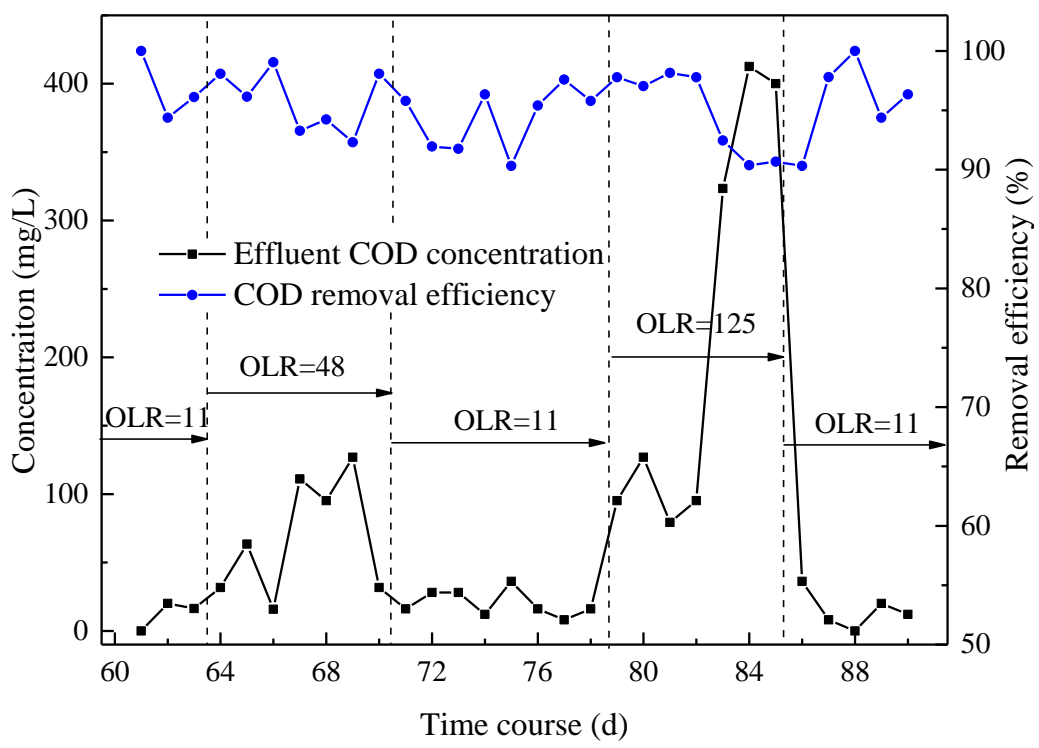

Figure 2. The COD removal under OC shock loadings 
The effluent COD concentration was greater than $100 \mathrm{mg} / \mathrm{L}$ and then increased to more than $500 \mathrm{mg} / \mathrm{L}$ when there was a sudden increase of OLR from $11 \mathrm{gCOD} /(\mathrm{gMLSS} \cdot \mathrm{d})$ to $125 \mathrm{gCOD} /(\mathrm{gMLSS} \cdot \mathrm{d})$. However, when the influent OLR declined to $11 \mathrm{gCOD} /(\mathrm{gMLSS} \cdot \mathrm{d})$, the effluent COD concentration dropped rapidly and restored to the original level, which demonstrated that the $\mathrm{A}^{2} \mathrm{O}$ system could remove high loads of carbon and recover low carbon concentration in the effluent after high shock loading.

\section{The influences of $O C$ shock loading on nitrogen removal performance}

The nitrogen removal performances of the $\mathrm{A}^{2} \mathrm{O}$ process under organic shock loading were plotted in Figure 3. As the influent OLR increased sharply from $11 \mathrm{gCOD} /(\mathrm{gMLSS} \cdot \mathrm{d})$ to $48 \mathrm{gCOD} /(\mathrm{gMLSS} \cdot \mathrm{d})$, negligible variations of the $\mathrm{NH}_{4}{ }^{+}-\mathrm{N}$ removal efficiency and the effluent $\mathrm{NH}_{4}{ }^{+} \mathrm{N}$ concentration were detected and their average values were $96.57 \%$ and $1.93 \mathrm{mg} / \mathrm{L}$, respectively. Satisfactory TN removal was also achieved when the influent OLR increased. And meanwhile, $\mathrm{NO}_{3}{ }^{-}-\mathrm{N}$ concentration in the effluent reduced compared with that under normal OC feeding condition. The effluent $\mathrm{NO}_{3}{ }^{-}$was between $14.50 \mathrm{mg} / \mathrm{L}$ and $15.45 \mathrm{mg} / \mathrm{L}$ and the average value was $14.86 \mathrm{mg} / \mathrm{L}$ under normal OC feeding condition, however, the effluent $\mathrm{NO}_{3}{ }^{-} \mathrm{N}$ was between $11.13 \mathrm{mg} / \mathrm{L}$ and $13.15 \mathrm{mg} / \mathrm{L}$ and the average value was $12.19 \mathrm{mg} / \mathrm{L}$ when influent OLR increased. In the aerobic zones, $\mathrm{NH}_{4}{ }^{+}-\mathrm{N}$ was converted into $\mathrm{NO}_{3}{ }^{-} \mathrm{N}$ by nitrifiers with the presence of DO. Nitrifiers are autotrophic microorganisms and efficient nitrogen removal could be achieved if there is enough hydraulic retention time and sufficient DO. The total nitrogen (TN) removal efficiency was up to $91 \%$ with an effluent $\mathrm{TN}$ concentration of $4.6 \mathrm{mg} / \mathrm{L}$, which was improved when the $\mathrm{A}^{2} \mathrm{O}$ system encountered low organic shock loading. The TN removal efficiency declined with an effluent concentration of $10 \mathrm{mg} / \mathrm{L}$ when the influent OLR was recovered from $48 \mathrm{gCOD} /(\mathrm{gMLSS} \cdot \mathrm{d})$ to $11 \mathrm{gCOD} /(\mathrm{gMLSS} \cdot \mathrm{d})$. Since variations of effluent $\mathrm{NH}_{4}{ }^{+}-\mathrm{N}$ and the corresponding $\mathrm{NH}_{4}{ }^{+}-\mathrm{N}$ removal efficiency under low organic carbon surge were small under low organic carbon surge when compared with that of the TN, the improved TN removal efficiency was thus attributed to the instantaneous improvement of denitrification rate when the system encountered OC surges.

During the high OC shock loading, the $\mathrm{NH}_{4}{ }^{+}-\mathrm{N}$ concentration in effluent ranged from $1.68 \mathrm{mg} / \mathrm{L}$ to $3.87 \mathrm{mg} / \mathrm{L}$ with an average value of $2.53 \mathrm{mg} / \mathrm{L}$, which was comparable to that before shock loading. The removal efficiencies of $\mathrm{TN}$ exceeded $85 \%$ with an average effluent TN concentration of $10.5 \mathrm{mg} / \mathrm{L}$. The removal efficiencies of TN decreased when the OLR returned from high value to low value because of the absence of carbon sources.

Nitrification and denitrification rate were two key indexes for the evaluation of the nitrogen removal efficiency. The variation of $\mathrm{NH}_{4}{ }^{+}-\mathrm{N}$ concentration between influent and effluent was used to calculate the nitrification rate (Mino et al., 1995; Li and Irvin, 2007). The equation was as follows (Eq. 1):

$$
r_{N}=\frac{d c_{N H_{4}^{+}-N}}{d t}\left(\frac{m g \cdot N}{L . h}\right)
$$




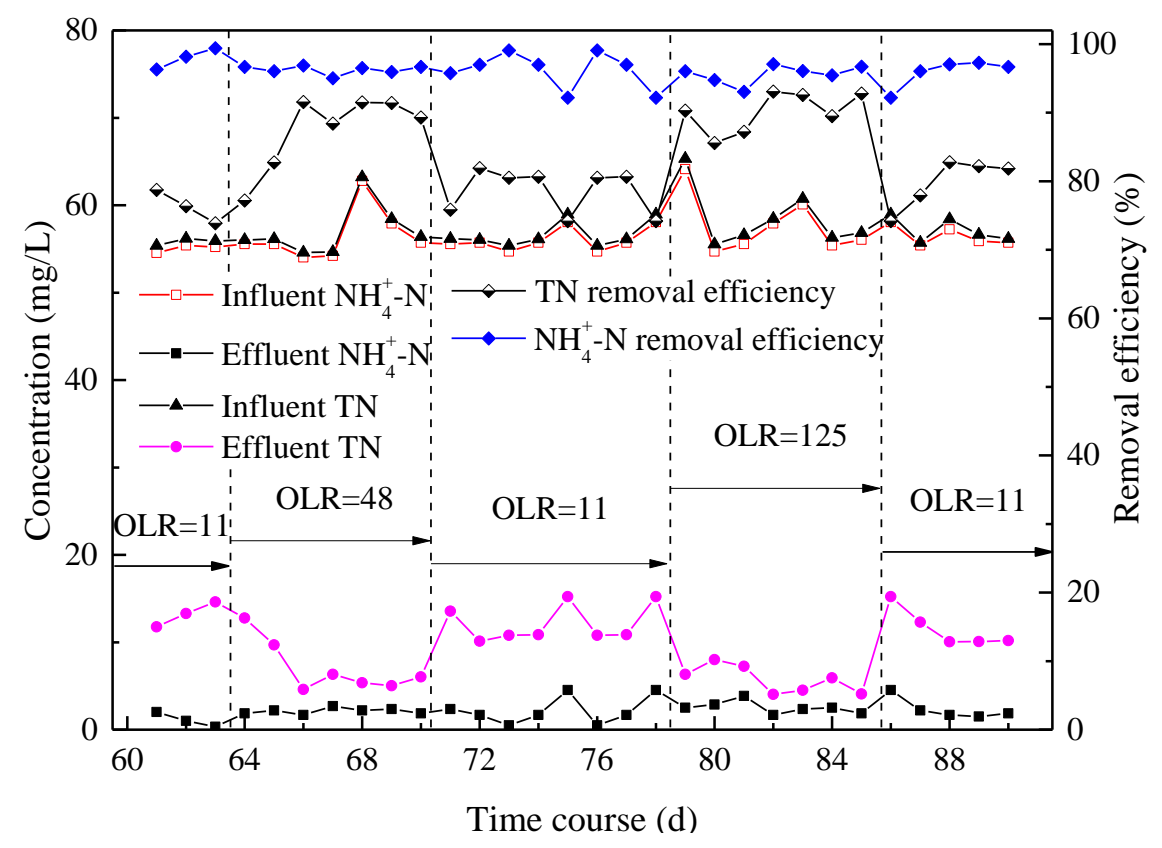

Figure 3. Nitrogen removal under OC shock loadings

The variations of nitrification rate under different OLR were shown in Figure 4. Initially, the nitrification rate showed an arising trend when the OLR of influent increased from $11 \mathrm{gCOD} /(\mathrm{gMLSS} \cdot \mathrm{d})$ to $48 \mathrm{gCOD} /(\mathrm{gMLSS} \cdot \mathrm{d})$ and then declined as the shock loading continued. The figure increased to the original level at the end of the shock loading. The nitrification rate increased from $1.20 \mathrm{mg} /(\mathrm{L} \cdot \mathrm{h})$ to $1.26 \mathrm{mg} /(\mathrm{L} \cdot \mathrm{h})$ and then slightly reduced to $1.25 \mathrm{mg} /(\mathrm{L} \cdot \mathrm{h})$ when the $\mathrm{A}^{2} \mathrm{O}$ system was subjected to a OLR of $125 \mathrm{gCOD} /(\mathrm{gMLSS} \cdot \mathrm{d})$. The variation of the nitrification rate was small when the $\mathrm{A}^{2} \mathrm{O}$ system suffered high OLR.

Two steps are involved in the denitrification process, of which $\mathrm{NO}_{3}{ }^{-} \mathrm{N}$ is reduced to $\mathrm{NO}_{2}^{-}-\mathrm{N}$ and then $\mathrm{NO}_{2}^{-}-\mathrm{N}$ is further reduced to $\mathrm{N}_{2}$. The difference between the sum of influent $\mathrm{NH}_{4}{ }^{+}-\mathrm{N}, \mathrm{NO}_{2}{ }^{-}-\mathrm{N}$ and $\mathrm{NO}_{3}{ }^{-}-\mathrm{N}$ in the anoxic zones and the sum of effluent $\mathrm{NH}_{4}{ }^{+}-\mathrm{N}, \mathrm{NO}_{2}{ }^{-}-\mathrm{N}$ and $\mathrm{NO}_{3}{ }^{-}-\mathrm{N}$ was utilized to calculate the denitrification rate (Liu et al., 2014; Shen et al., 2016). The calculation equation was as follows (Eq. 2):

$$
r_{N}=\frac{d\left(c_{N H_{4}^{+}-N}+c_{N O_{2}^{-}-N}+c_{N O_{3}^{-}-N}\right)}{d t}\left(\frac{m g \cdot N}{L . h}\right)
$$

As shown in Figure 4, the denitrification rate was improved with the increase of influent COD concentration. The denitrification rate increased from $1.17 \mathrm{mg} \cdot \mathrm{N} /(\mathrm{L} \cdot \mathrm{h})$ to $2.11 \mathrm{mg} \cdot \mathrm{N} /(\mathrm{L} \cdot \mathrm{h})$ when the influent OLR ascended from $11 \mathrm{gCOD} /(\mathrm{gMLSS} \cdot \mathrm{d})$ to $125 \mathrm{gCOD} /(\mathrm{gMLSS} \cdot \mathrm{d})$. Consequently, OLR increases were beneficial for the denitrification process by providing sufficient carbon source.

\section{The influences of $A N$ shock loading on the $C O D$ removal performance}

As shown in Figure 5, the effluent COD concentration was below $30 \mathrm{mg} / \mathrm{L}$ and the corresponding removal efficiency was greater than $95 \%$ when high influent AN concentration $(110 \mathrm{mg} / \mathrm{L})$ was provided. The COD removal performance of the $\mathrm{A}^{2} \mathrm{O}$ 
system was not influenced by the increase of influent $\mathrm{NH}_{4}{ }^{+}-\mathrm{N}$ concentration as sufficient HRT was provided and the influent OLR was $11 \mathrm{gCOD} /(\mathrm{gMLSS} \cdot \mathrm{d})$. It is indicated that in the biological system, the removal of organic pollutants was started ahead of the nitrification process as the nitrification reaction was slower and more sensitive to environmental conditions than carbon oxidation by heterotrophs in the biological system (Liang et al., 2010). Hence, the influence of $\mathrm{NH}_{4}{ }^{+}-\mathrm{N}$ concentration variation on the $\mathrm{COD}$ removal of the $\mathrm{A}^{2} \mathrm{O}$ process was very small and could be neglected under the condition of a relative high $\mathrm{AN}$ concentration in the $\mathrm{A}^{2} \mathrm{O}$ process.

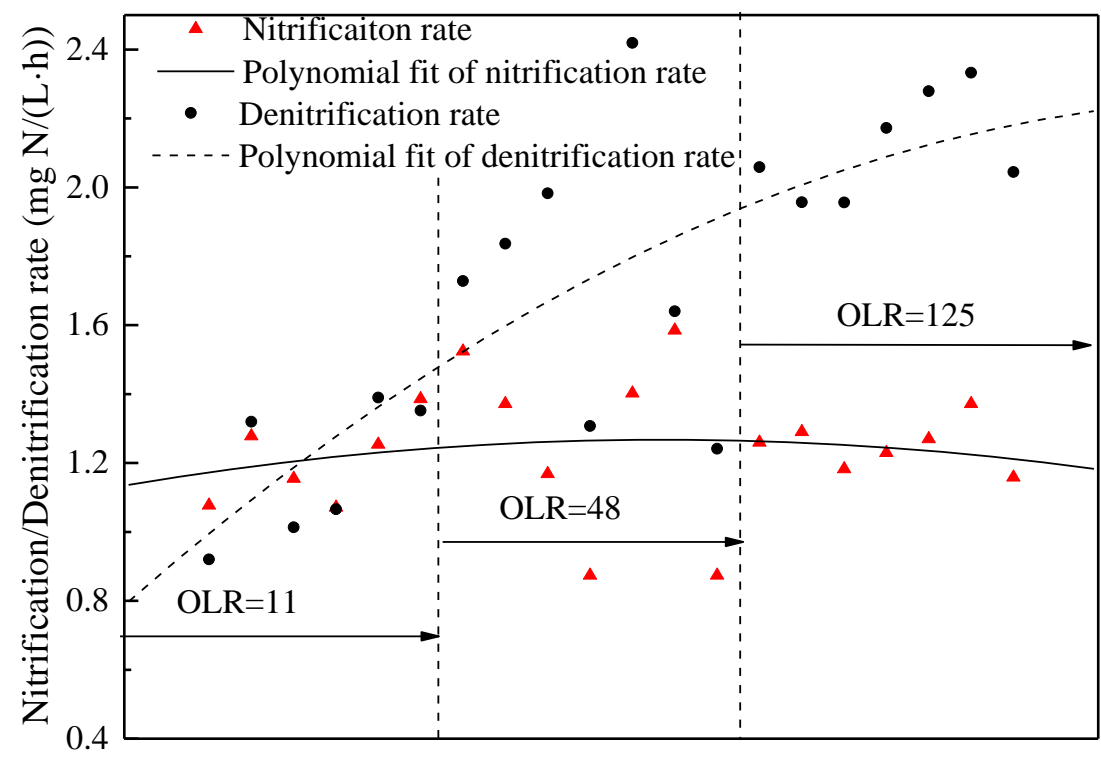

Different OC loadings

Figure 4. Variations of nitrification and denitrification rate under OC shock loadings

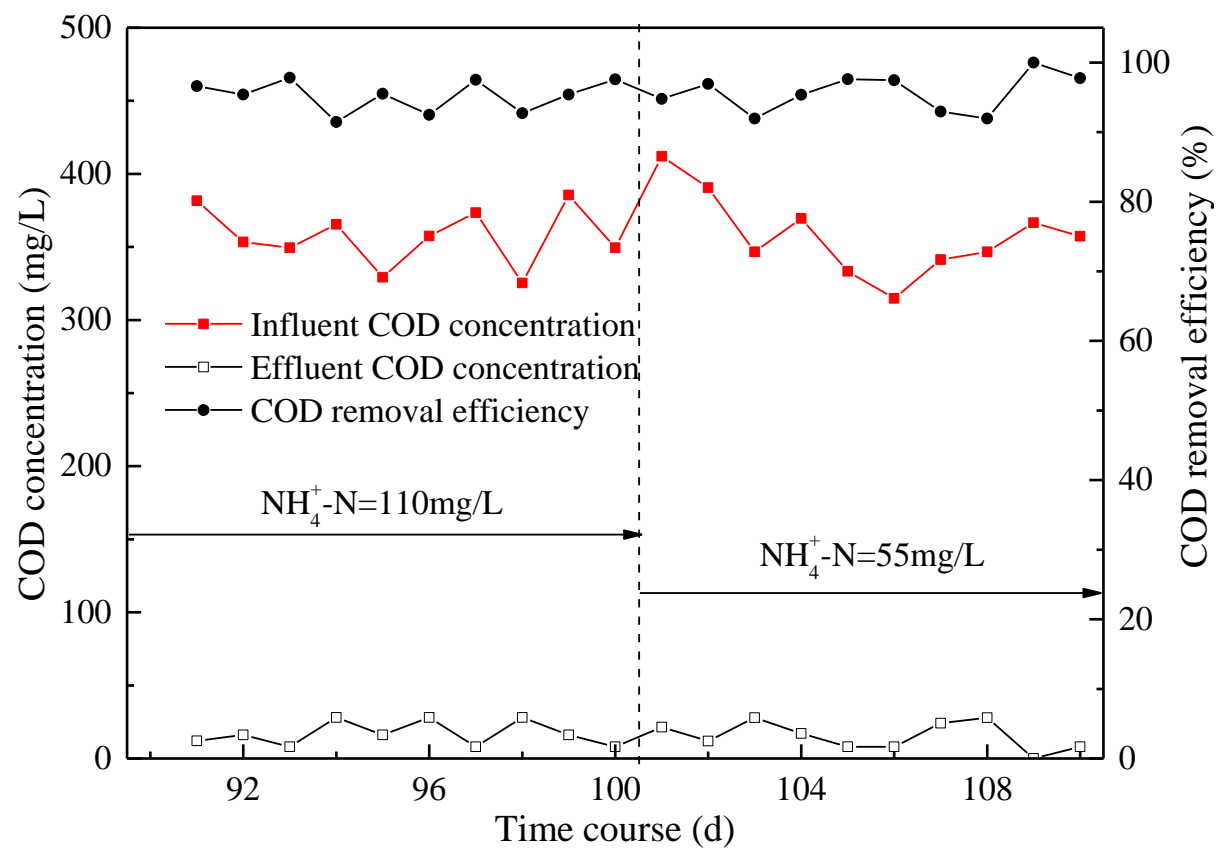

Figure 5. COD removal performance under AN shock loading 


\section{The influences of AN shock loading on the nitrogen removal performance}

As shown in Figure 6, the nitrogen removal efficiency of the $\mathrm{A}^{2} \mathrm{O}$ process under high influent $\mathrm{NH}_{4}{ }^{+}-\mathrm{N}$ concentration $(110 \mathrm{mg} / \mathrm{L})$ was evaluated by the removal performance of $\mathrm{NH}_{4}{ }^{+}-\mathrm{N}$ and $\mathrm{TN}$. The effluent $\mathrm{NH}_{4}{ }^{+} \mathrm{N}$ concentration was below $5 \mathrm{mg} / \mathrm{L}$ with a removal efficiency of $95 \%$ on the first day. The effluent $\mathrm{NH}_{4}{ }^{+}-\mathrm{N}$ concentration began to increase along with the duration of the AN shock loading and was higher than $60 \mathrm{mg} / \mathrm{L}$ at the end of the AN shock loading. It was assumed that at the initial stage of the AN surge, high $\mathrm{NH}_{4}{ }^{+}-\mathrm{N}$ concentration was buffered by the remaining reactor contents within the range that the nitrifiers could effectively convert $\mathrm{NH}_{4}{ }^{+}-\mathrm{N}$ to $\mathrm{NO}_{2}{ }^{-} \mathrm{N}$ and $\mathrm{NO}_{3}{ }^{-}$ $-\mathrm{N}$. Gradually, the effluent $\mathrm{NH}_{4}{ }^{+}-\mathrm{N}$ concentration increased as the continuous feed of excessive $\mathrm{NH}_{4}{ }^{+}-\mathrm{N}$ exceeded the nitrifying ability of the microorganisms in the $\mathrm{A}^{2} \mathrm{O}$ process. The effluent $\mathrm{NH}_{4}{ }^{+}-\mathrm{N}$ concentration declined to $29 \mathrm{mg} / \mathrm{L}$ when the AN shock loading ceased. Then the effluent $\mathrm{NH}_{4}{ }^{+}-\mathrm{N}$ concentration gradually returned to the original level before the occurrence of AN shock loading.

The removal performance of TN was similar to that of $\mathrm{NH}_{4}{ }^{+}-\mathrm{N}$. The effluent TN was $8 \mathrm{mg} / \mathrm{L}$ and $90 \%$ removal efficiency was obtained on the first day of the AN shock loading. The effluent TN concentration increased to more than $70 \mathrm{mg} / \mathrm{L}$ at the end of the AN shock loading possibly due to the accumulation of nitrite and nitrate.

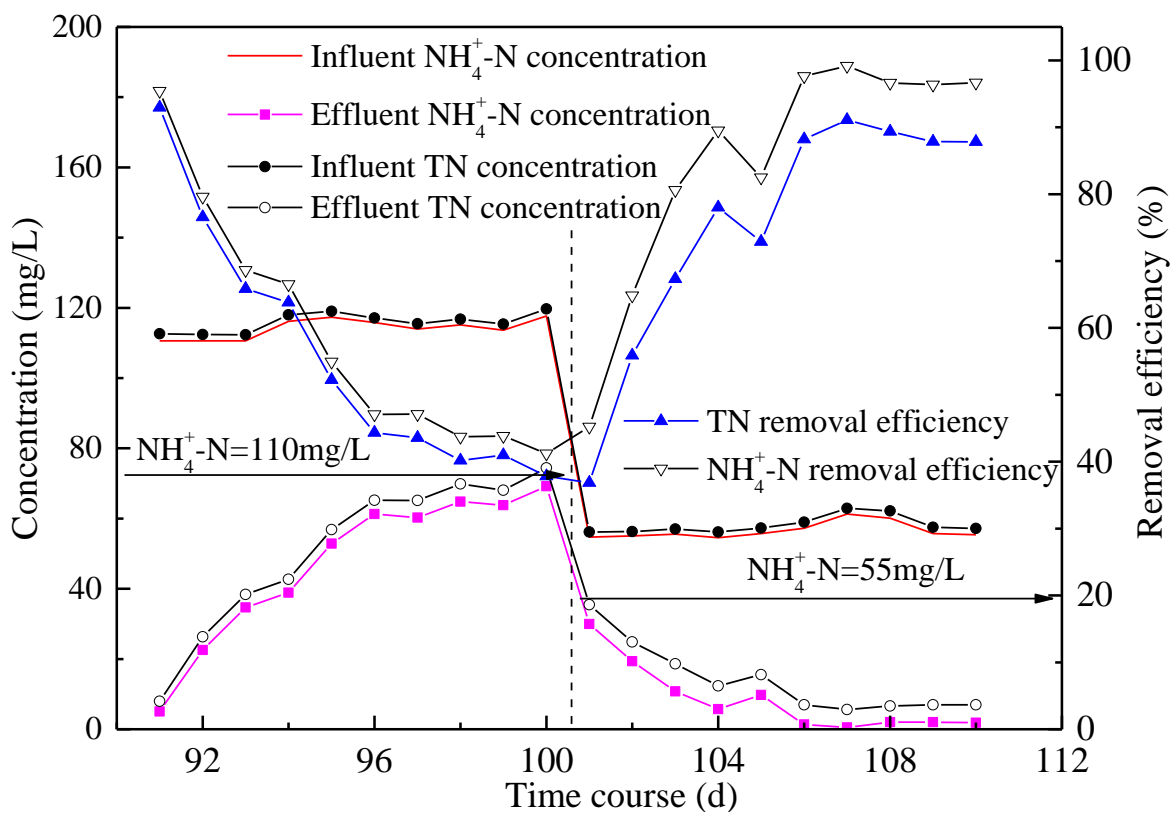

Figure 6. Nitrogen removal performance under AN shock loading

As shown in Figure 7, the nitrification rate ranged from $1.36 \mathrm{mg} \cdot \mathrm{N} /(\mathrm{L} \cdot \mathrm{h})$ to $0.58 \mathrm{mg} \cdot \mathrm{N} /(\mathrm{L} \cdot \mathrm{h})$ under the AN shock loading, whereas the denitrification rate varied in a range between $0.57 \mathrm{mg} \cdot \mathrm{N} /(\mathrm{L} \cdot \mathrm{h})$ and $2.46 \mathrm{mg} \cdot \mathrm{N} /(\mathrm{L} \cdot \mathrm{h})$. It was demonstrated that high nitrogen-loading rate can provoke the inhibition of nitrification and consequently the BNR instability (Jubany et al., 2008; Torà et al., 2011). In the present study, the variation of the denitrification rate were more remarkable than that of the nitrification rate, indicating that the AN shock loading interference with the nitrification process and the denitrification process was further influenced as the former provided the reaction source for the latter. 


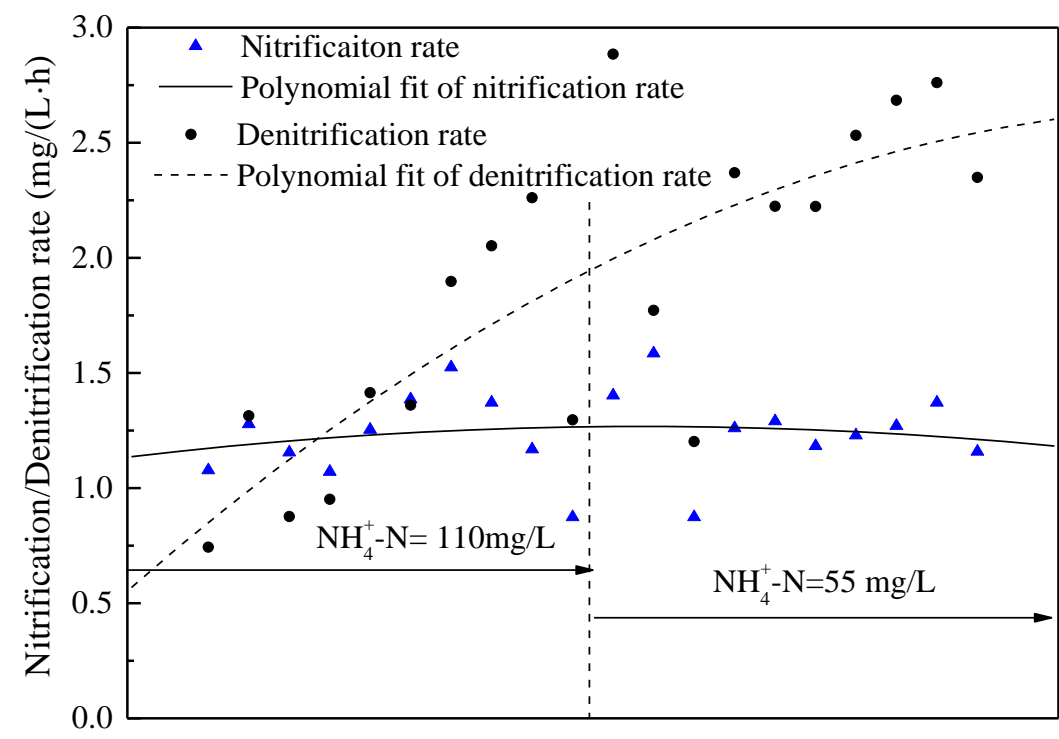

Different AN loadings

Figure 7. Variations of nitrification and denitrification rate under AN shock loadings

\section{The influences of shock loading on EPS amount and SVI value}

The daily variations of LB-EPS, TB-EPS, the total EPS amounts and effluent COD were observed during $\mathrm{OC}$ and $\mathrm{AN}$ surges in the discharged mixed liquid from the last aerobic zone (shown in Fig. 8). The average values of different types of EPS, VSS (Volatile Suspended Solids) and SVI were summarized in Table 4.

Table 4. EPS amounts and SVI values during different shock loadings

\begin{tabular}{c|c|c|c|c|c|c}
\hline Experiment & LB (mg/L) & TB $(\mathbf{m g} / \mathbf{L})$ & EPS $(\mathbf{m g} / \mathbf{L})$ & SVI $(\mathbf{m L} / \mathbf{g})$ & VSS (mg/L) & $\begin{array}{c}\text { Effluent } \\
\text { appearance }\end{array}$ \\
\hline Phase I & 161.8 & 252.1 & 413.9 & 100 & 1210 & Clean \\
Phase II & 99.4 & 297.9 & 397.3 & 87 & 1176 & Clean \\
Phase III & 194.5 & 278.7 & 473.2 & 200 & 1290 & Turbid \\
Phase IV & 83.4 & 231.0 & 314.5 & 80 & 1105 & Clean \\
\hline
\end{tabular}

During the low OC shock loading, the LB-EPS amount showed a dramatic reduction and then stabilized at approximately $60 \mathrm{mg} / \mathrm{L}$, whereas the variations of TB-EPS amount fluctuated at a range of $265.1-343.2 \mathrm{mg} / \mathrm{L}$ with an average value of $297.9 \mathrm{mg} / \mathrm{L}$. The amount of total EPS increased in the first 3 days and then dropped in the following days. Meanwhile, the effluent COD increased when there was an influent OC shock loading at the initial stage and then decreased with prolonged shock loading, which might be due to the acclimation of microorganisms to shock loadings. VSS was decreased from $1201 \mathrm{mg} / \mathrm{L}$ to $1176 \mathrm{mg} / \mathrm{L}$, and furthermore, the sludge volume index (SVI) descended from $100 \mathrm{~mL} / \mathrm{g}$ to $87 \mathrm{~mL} / \mathrm{g}$ and the effluent quality was affected as indicated by the variations of effluent $\mathrm{NH}_{4}{ }^{+}-\mathrm{N}, \mathrm{TN}$ and COD concentrations. Gentle variations of the LB-EPS amount were observed when the influent OLR increased sharply from $11 \mathrm{gCOD} /(\mathrm{gMLSS} \cdot \mathrm{d})$ to $125 \mathrm{gCOD} /(\mathrm{gMLSS} \cdot \mathrm{d})$. The TB-EPS amount 
increased to an average value of $297.9 \mathrm{mg} / \mathrm{L}$ and then became constant with the proceeding of high OC shock loading. The total EPS amount and VSS were up to $473.2 \mathrm{mg} / \mathrm{L}$ and $1290 \mathrm{mg} / \mathrm{L}$, respectively, which were much higher than situation without shock loading. An average SVI value of $200 \mathrm{~mL} / \mathrm{g}$ was obtained when the $\mathrm{A}^{2} \mathrm{O}$ system suffered high OC shock loading. During AN shock loading, the LB-EPS amount increased to $167.2 \mathrm{mg} / \mathrm{L}$ and then showed a sharp reduction from the $3^{\text {rd }}$ day. The TBEPS and LB-EPS amounts showed a similar trend. The average SVI value and VSS were $80 \mathrm{~mL} / \mathrm{g}$ and $1105 \mathrm{mg} / \mathrm{L}$, respectively, and the effluent had a clean appearance.

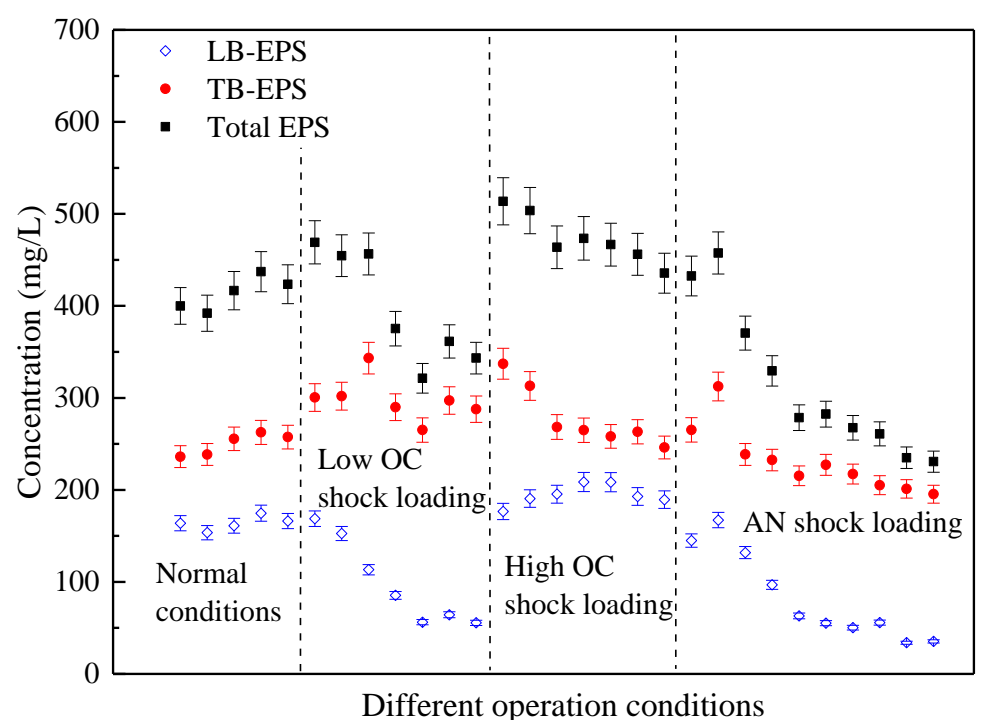

Figure 8. Variations of LB-EPS, TB-EPS and the total EPS amounts

It is indicated that low OC shock loading could lead to the temporary increase of the EPS amount, whereas the LB-EPS amount and VSS declined when the low OC shock loading continued. When the $\mathrm{A}^{2} \mathrm{O}$ process was subjected to high OC shock loading, the amount of LB-EPS and VSS showed a milder variation compared with TB-EPS. The total EPS amount and VSS during high OC shock loading were the highest among all operational conditions. All types of EPS amount and VSS declined in the long-term operation when the $\mathrm{A}^{2} \mathrm{O}$ process experienced the $\mathrm{AN}$ shock loading.

In this work, the SVI values were in good agreement with the LB-EPS (or total EPS) concentration and VSS. It is indicated that the LB-EPS had a negative effect on sludge flocculation and excessive EPS in the form of LB-EPS could weaken cell attachment and result in poor flocculation (Xu et al., 2016). Along with the increase of LB-EPS concentration and VSS, the presence of a large number of fine flocs significantly reduced the effluent quality and the activated sludge settleability. Zhang and Yang (2015) also found that LB-EPS had a negative effect on the sludge settleability as an increase in LB-EPS content might bring more bound water into the aggregates, and therefore produced highly porous flocs with a low density.

\section{Discussion}

As a widely applied biological wastewater treatment process, the $\mathrm{A}^{2} \mathrm{O}$ process was resistant to all the shock loadings and produced high quality effluents once the shock 
loading ceased. However, the effluent deteriorated when the system was subjected to high-strength or prolonged shock loadings. The use of real-time control systems were thus proposed to optimize processes under various effluent and environmental conditions ( $\mathrm{Li}$ et al., 2016). The $\mathrm{A}^{2} \mathrm{O}$ system was capable of removing more organic carbon at higher OLR and the elevated carbon source supply was beneficial for the removal of nitrogen compounds.

The heterotrophic microorganisms showed fast proliferation and became dominant in the anaerobic zones owing to the sufficient organic compounds in the influent. In the anoxic zones, heterotrophic facultative denitrifying bacteria could utilize the $\mathrm{NO}_{\mathrm{x}}{ }^{-} \mathrm{-N}$ as the electron acceptor and the denitrification rate was higher under a relative high influent OC. In the aerobic zones, the growth of heterotrophic microorganisms was restricted due to the low organic compounds from the anoxic zones and nitrifying bacteria became the dominant bacteria under sufficient DO. The COD in aerobic and anoxic zones was lower than $50 \mathrm{mg} / \mathrm{L}$ when the influent COD was $414 \mathrm{mg} / \mathrm{L}$. The difference between effluent COD in aerobic zone and effluent COD in anoxic zone was slight. Therefore, a large portion of the organic substrate was consumed in the anaerobic and anoxic reactors of the $\mathrm{A}^{2} \mathrm{O}$ process. Low concentration of organic compounds could not meet the demand of the growth of heterotrophic microorganisms in the aerobic zones. Previous literature indicated that the increase of COD concentration would induce the competition of the heterotrophic microorganisms and the nitrifiers for DO, nutrients, space or other ecological factors (Zhu and Chen, 2001; Tsuno et al., 2002). Ling and Chen (2005) also reported that the decrease of nitrification rate with the addition of $\mathrm{OC}$ and the nitrification rate was lower when the OC was higher. In this study, a large portion of organic substrate was already consumed in the anaerobic and anoxic zones of the multistage $\mathrm{A}^{2} \mathrm{O}$ process. The level of COD in the aerobic zones was thus below the concentration to induce the competition between the heterotrophic microorganisms and the nitrifiers since sufficient HRT and DO concentration were provided for the growth and reproduction of heterotrophs and nitrifiers.

On the contrary, the denitrifiers in the anoxic zones demand external carbon source for denitrification. The denitrification step reduces nitrate to nitrogen gas by many species of heterotrophic facultative bacteria and require biodegradable organic carbon to perform metabolic processes. Enough carbon must be available for the complete denitrification of nitrate formed during the nitrification (Wunderlich et al., 2012; Xie et al., 2012; Xu et al., 2018). In our study, similar results were obtained and denitrification efficiency was improved in the anaerobic zones under high influent OLR. However, compared with high OLR shock loading, denitrification efficiency was lower in the anaerobic zones under the low OLR shock loading. An external carbon source addition was proposed to raise the denitrification rate when needed to compensate for high nitrogen loads or low seasonal temperatures (Han et al., 2010). The external COD addition was known as a feasible and flexible strategy to increase the denitrification rate when the COD concentration was low and could not cope with the current nitrogen load (Majumder et al., 2008). However, at a high $\mathrm{C} / \mathrm{N}$ ratio, Michaud (Michaud et al., 2006) reported that heterotrophic bacteria outcompeted nitrifiers for available oxygen and space in the biofilter media, which deteriorated the nitrification process and led to nitrate deficiency for the denitrification. The present study showed that the majority of organic compounds were consumed in the anaerobic and anoxic zones. Therefore, the COD concentration was relative low in the aerobic zones, which resulted in low 
multiplication rate of heterotrophic bacteria and high multiplication rate of nitrifiers in the aerobic zones. Consequently, the nitrification rate was high in the aerobic zones.

High AN concentration had slight influences on COD removal, but was detrimental to the removal of nitrogen compounds. Greater fluctuations were observed on the denitrification rate than the nitrification rate when the $\mathrm{A}^{2} \mathrm{O}$ was subjected to shock loadings. It was reported that the $\mathrm{COD} / \mathrm{N}$ ratio of 5-15 in the bioreactor was suitable for nitrification and denitrification reaction (Ding et al., 2011). The deficiency of carbon substrate resulted in the unbalance of nitrification and denitrification reactions and finally led to low overall nitrogen removal.

The nature and content of EPS are sensitive to the operational and environmental conditions. The LB-EPS, TB-EPS and total EPS amount showed an increase at the initial stage of the shock loadings and then declined with the prolonged shock loading. The characteristics of EPS in the activated sludge were closely connected with its resistant ability to shock loading and pollutants removal properties. SVI was widely used for characterizing sludge settleability and SVI values below $100 \mathrm{~mL} / \mathrm{g}$ were considered as an indication of good settling properties of the sludge (Satyawalia and Balakrishnan, 2009). The SVI value was changed in a similar trend with the variation of average LB-EPS and total EPS amounts. The amount of LB-EPS had great influences on the SVI value and VSS, and SVI increased with the increasing content of LB-EPS and VSS because LB-EPS was not bound tightly to the cell. Meanwhile, LB-EPS had open and loose structure, high moisture content, low density and large volume around the cell, which could result in the larger volume and smaller density of sludge flocs and furthermore weaken the compressibility of sludge flocs. On the contrary, the effect of the change of TB-EPS on the volume of sludge flocs was relative small because TBEPS was bound tightly to the cell and had tight structure, low moisture content and high density (Ruan et al., 2013). A long-term high shock loading leads to high LB-EPS and total EPS, which could influence the settleability of sludge and SVI increased. Substrate type and concentration, bacterial growth phase, the presence of toxic substances, shear rate of the bioreactor and other external conditions could influence the quantity and nature of EPS (Badireddy et al., 2008; Janus and Ulanicki, 2010; Li et al., 2015). At the initial state of each shock loading, the amounts of all types of EPS were elevated to a different level and SVI was increased with the increasing EPS. The temporary increase of EPS could be consequence of the necessity to acclimate to the new conditions. Moreover, a decline tendency was observed with the prolonged shock loadings. On the one hand, the bacterial cells tended to produce more EPS to protect themselves against unfavorable conditions (Sheng et al., 2008), which could be a possible reason for the temporary increase of EPS at the initial stage of the shock loading (Laspidou and Rittmann, 2002). On the other hand, the microorganisms could not adapt to the prolonged high organic loadings. The activity of microorganisms decreased and their cells could not autolyze when there was high substrate concentration. Therefore, less EPS was released when the system was under long-term high organic loadings (Shao et al., 2017). However, the EPS production rate is not necessary proportional to the substrate consumption rate. Laspidou and Rittmann (2002) demonstrated that the relationship between EPS production and substrate consumption rate depended on the kind of microorganisms involved and the system conditions. Consequently, the EPS variation could be an indication of the flocculation in microbial community of the $\mathrm{A}^{2} \mathrm{O}$ system. The LB-EPS amount declined dramatically during the low OC and AN shock loading, which was in accordance with the previous literatures that LB-EPS functioned 
as the primary surface for cell interaction and attachment (Sheng et al., 2008). The LBEPS increased initially when the biological system was under high OC loading and then its amount decreased. The temporarily increased LB-EPS may cover the surface or fill the interior of the activated sludge flocs. As a result, the mass transfer of the substrates and the export of metabolic products were significantly prevented as described in the previous literature (Mu et al., 2006; Zheng and Yu, 2007). Consequently, a high level of EPS was not beneficial for biodegradation, which could be the reason for the effluent deterioration during the high OC shock loading. The highest EPS amount was accompanied by elevated effluent COD concentration and turbidity. Therefore, the composition of the activated sludge flocs changed, followed by the alteration of the physiochemical characteristics of the activated sludge as a result of shock loading.

\section{Conclusion}

The $\mathrm{A}^{2} \mathrm{O}$ process successfully withstood all the shock loadings and restored its performance once the shock loading ceased. The enhanced carbon source concentration was beneficial for the removal of nitrogen compounds in the $\mathrm{A}^{2} \mathrm{O}$ system. High $\mathrm{AN}$ concentration had slight influences on COD removal, but was detrimental to the removal of nitrogen compounds. Greater fluctuations were observed on the denitrification rate than the nitrification rate when the $\mathrm{A}^{2} \mathrm{O}$ was subjected to shock loadings. The LB-EPS, TB-EPS and total EPS amount showed an increase at the initial stage of the shock loadings and then declined with the prolonged shock loading. The SVI value varied in a similar trend with the variation of average LB-EPS and total EPS amounts. Smaller concentrations of LB-EPS and total EPS indicated a good settleability of the activated sludge.

Acknowledgements. The authors want to express their gratitude to the National Natural Science Foundation of China (grant numbers 51678119 and 51508073), and the Science and Technology Development Program of Jilin Province (grant numbers 20180201016SF, 20180101309JC and 20170519013JH) for their financial supports.

\section{REFERENCES}

[1] APHA (1998): Standard Methods for the Examination of Water and Wastewater, 20th ed. - American Public Health Association, Washington, DC.

[2] Badireddy, A. R., Chellam, S., Yanina, S., Gassman, P., Rosso, K. M. (2008): Bismuth dimercaptopropanol (BisBAL) inhibits the expression of extracellular polysaccharides and proteins by Brevundimonas diminuta: implications for membrane microfiltration. Biotechnology and Bioengineering 99(3): 634-643.

[3] Bassin, J. P., Kleerebezem, R., Dezotti, M., van Loosdrecht, M. C. M. (2012): Simultaneous nitrogen and phosphate removal in aerobic granular sludge reactors operated at different temperatures. - Water Research 46(12): 3805-3816.

[4] Chang, H., Yang, X., Fang, Y., Pu, P., Li, Z., Rengel, Z. (2006): In-situ nitrogen removal from the eutrophic water by microbial-plant integrated system. - Journal of Zhejiang University Science B 7(7): 521-531.

[5] Chen, B., Kim, Y., Westerhoff, P. (2011): Occurrence and treatment of wastewaterderived organic nitrogen. - Water Research 45(15): 4641-4650. 
[6] Ding, D. H., Feng, C. P., Jin, Y. X., Hao, C. B., Zhao, Y. X., Suemura, T. (2011): Domestic sewage treatment in a sequencing batch biofilm reactor (SBBR) with an intelligent controlling system. - Desalination 276(1-3): 260-265.

[7] Guo, H., Zhou, J., Su, J., Zhang, Z. (2005): Integration of nitrification and denitrification in airlift bioreactor. - Biochemical Engineering Journal 23(1): 57-62.

[8] Han, H., Li, Y., Hu, H., Wang, B. (2010): Effect of external carbon source on denitrification in biofilter at low temperature. - Advanced Materials Research 113-116: 1358-1362.

[9] Janus, T., Ulanicki, B. (2010): Modelling SMP and EPS formation and degradation kinetics with an extended ASM3 model. - Desalination 261(1-2): 117-125.

[10] Jubany, I., Carrera, J., Lafuente, J., and Baeza, J. A. (2008): Start-up of a nitrification system with automatic control to treat highly concentrated ammonium wastewater: experimental results and modelling. - Chemical Engineering Journal 144(3): 407-419.

[11] Laspidou, C. S., Rittmann, B. E. (2002): A unified theory for extracellular polymeric substances, soluble microbial products, and active and inert biomass. - Water Research 36(11): 2711-2720.

[12] Li, B., Irvin, S. (2007): The comparison of alkalinity and ORP as indicators for nitrification and denitrification in a sequencing batch reactor (SBR). - Biochemical Engineering Journal 34(3): 248-255.

[13] Li, D., Wu, Q., Liang, Y. H., Su, Q. L., Zhang, J. K., Wei, J. J., Zhang, J. (2015): Effect of substrate concentration and type on the content of extracellular polymeric substances in the nitrification sludge. - Journal of Harbin Institute of Technology 47(4): 81-86 (in Chinese).

[14] Li, G. R., Li, Q., Cao, S. S., Su, J. P., Fan, R. C. (2016): Effect of carbon source on nitrogen and phosphorus removal efficiency of an $\mathrm{A}^{2} / \mathrm{O}$ system. - Environmental Engineering 9(6): 22-25 (in Chinese).

[15] Li, X., Li, Y., Liu, H., Hua, Z., Du, G., Chen, J. (2008): Correlation between extracellular polymeric substances and aerobic biogranulation in membrane bioreactor. - Separation and Purification Technology 59(1): 26-33.

[16] Li, X. L., Wei, L. L., Zhao, Q. L., Chen, Z. Q. (2014): Effects and mechanisms of polymeric aluminum-iron (PAFC) added of aeration tank in $\mathrm{A}^{2} \mathrm{O}$ systems for phosphorus and nitrogen removal. - Research of Environmental Sciences 27(10): 1212-1218 (in Chinese).

[17] Liang, Z., Li, W., Yang, S., Du, P. (2010): Extraction and structural characteristics of extracellular polymeric substances (EPS), pellets in autotrophic nitrifying biofilm and activated sludge. - Chemosphere 81(5): 626-632.

[18] Ling, J., Chen, S. L. (2005): Impact of organic carbon on nitrification performance of different biofilters. - Aquacultural Engineering 33(2): 150-162.

[19] Liu, X. Y., Lin, H., Ma, Z. R., Wang, L., Liu, J. W., Guo, C., Jiang, Y. H. (2014): Characteristics of nitrification and denitrification for simultaneous nitrogen and phosphorus remova. - Environmental Science 35(01): 214-220 (in Chinese).

[20] Ma, J., Zhang, Y., Liu, L., Fu, B. (2006): Nitrogen removal effect of A2/O process. Journal of Harbin University (Natural Sciences Edition) 22(1): 28-31 (in Chinese).

[21] Majumder, P. S., Gupta, S. K. (2008): Effect of carbon sources and shock loading on the removal of chlorophenols in sequential anaerobic-aerobic reactors. - Bioresource Technology 99(8): 2930-2937.

[22] Michaud, L., Blancheton, J. P., Bruni, V., Piedrahita, R. (2006): Effect of particulate organic carbon on heterotrophic bacterial populations and nitrification efficiency in biological filters. - Aquacultural Engineering 34(3): 224-233.

[23] Mino, T., Liu, W. T., Kurisu, F., Matsuo, T. (1995): Modeling glycogen-storage and denitrification capability of microorganisms in enhanced biological phosphate removal processes. - Water Science and Technology 31(2): 25-34. 
[24] $\mathrm{Mu}, \mathrm{Y} ., \mathrm{Yu}, \mathrm{H} ., \mathrm{Wang}$, G. (2006): Permeabilities of anaerobic $\mathrm{CH}_{4}$-producing granules. Water Research 40(9): 1811-1815.

[25] Pai, T. Y., Chiou, R. J., Tzeng, C. J., Lin, T. S., Yeh, S. C., Sung, P. J., Tseng, C. H., Tsai, C. H., Tai, Y. S., Hsu, W. J., Wei, Y. L. (2010): Variation of biomass and kinetic parameters for nitrifying species in the TNCU3 process at different aerobic hydraulic retention times. - World Journal of Microbiology and Biotechnology 26(4): 589-597.

[26] Park, S., Bae, W., Rittmann, B. E., Kim, S., Chung, J. (2010): Operation of suspendedgrowth shortcut biological nitrogen removal (SSBNR) based on the minimum/maximum substrate concentration. - Water Research 44(5): 1419-1428.

[27] Peng, Y. Z., Wang, X. L., Li, B. K. (2006): Anoxic biological phosphorus uptake and the effect of excessive aeration on biological phosphorus removal in the $\mathrm{A}^{2} \mathrm{O}$ process. Desalination 189(1-3): 155-164.

[28] Ruan, X. D. (2013): Flocculation characteristics of flocs formed by tightly bound extracellular polymeric substances (TB-EPS)-the formation, breakup and regrowth of flocs. - Acta Scientiae Circumstantiae 33(3): 655-663 (in Chinese).

[29] Satyawali, Y., Balakrishnan, M. (2009): Effect of PAC addition on sludge properties in an MBR treating high strength wastewater. - Water Research 43(6): 1577-1588.

[30] Seifi, M., Fazaelipoor, M. H. (2012): Modeling simultaneous nitrification and denitrification (SND) in a fluidized bed biofilm reactor. - Applied Mathematical Modelling 36(11): 5603-5613.

[31] Shao, Y. X., Shi, Y. J., Mohammed, A., Liu, Y. (2017): Wastewater ammonia removal using an integrated fixed-film activated sludge-sequencing batch biofilm reactor (IFASSBR): comparison of suspended flocs and attached biofilm. - International Biodeterioration and Biodegradation 116: 38-47.

[32] Shen, Y. J., Wu, Y., Zhang, X. X. (2016): Influence of the different test methods on the determination of activated sludge denitrification rate. - Shandong Chemical 45(05): 7-11 (in Chinese).

[33] Sheng, G. P., Zhang, M. L., Yu, H. Q. (2008): Characterization of adsorption properties of extracellular polymeric substances (EPS) extracted from sludge. - Colloids and Surfaces B: Biointerfaces 62(1): 83-90.

[34] Sheng, G. P., Yu, H. Q., Li, X. Y. (2010): Extracellular polymeric substances (EPS) of microbial aggregates in biological wastewater treatment systems: A review. Biotechnology Advances 28(6): 882-894.

[35] Shou, W. J., Kang, F. X., Lu, J. H. (2018): Nature and value of freely dissolved eps ecosystem services: insight into molecular coupling mechanisms for regulating metal toxicity. - Environmental Science and Technology 52(2): 457-466.

[36] Tanabene, R., Genty, T., Carolina, G. M., Bruno, B., Potvin, R., Neculita, C. M. (2018): Nitrification-denitrification of thiocyanate, ammonia, and nitrates in highly contaminated gold mine effluents using methanol as energy source. - Journal of Environmental Engineering 144(5): 1-6.

[37] Torà, J. A., Baeza, J. A., Carrera, J., Oleszkiewicz, J. A. (2011): Denitritation of a highstrength nitrite wastewater in a sequencing batch reactor using different organic carbon sources. - Chemical Engineering Journal 172(2-3): 994-998.

[38] Tsuno, H., Hidaka, T., Nishimura, F. (2002): A simple biofilm model of bacterial competition for attached surface. - Water Research 36(4): 996-1006.

[39] Walters, E., Hille, A., He, M., Ochmann, C., Horn, H. (2009): Simultaneous nitrification/denitrification in a biofilm airlift suspension (BAS) reactor with biodegradable carrier material. - Water Research 43(18): 4461-4468.

[40] Wang, X. L., Peng, Y. Z., Wang, S. Y., Fan, J., Cao, X. M. (2006): Influence of wastewater composition on nitrogen and phosphorus removal and process control in $\mathrm{A}^{2} \mathrm{O}$ process. - Bioprocess and Biosystems Engineering 28(6): 397-404. 
[41] Wunderlich, A., Meckenstock, R., Einsiedl, F. (2012): Effect of different carbon substrates on nitrate stable isotope fractionation during microbial denitrification. Environmental Science and Technology 46(9): 4861-4868.

[42] Xie, L., Chen, J. R., Wang, R., Zhou, Q. (2012): Effect of carbon source and COD/NO ${ }_{3}^{-}$$\mathrm{N}$ ratio on anaerobic simultaneous denitrification and methanogenesis for high-strength wastewater treatment. - Journal of Bioscience and Bioengineering 113(6): 759-764.

[43] Xu, F., Li, Y., Huang, Y. (2009): Effect of inner circumfluence rate on the performance of continuous-flow improved $\mathrm{A}^{2} / \mathrm{O}$ reactor. - Technology of Water Treatment 35(8): 5962 (in Chinese).

[44] Xu, J., Yu, H. Q., Li, X. Y. (2016): Probing the contribution of extracellular polymeric substance fractions to activated-sludge bioflocculation using particle image velocimetry in combination with extended DLVO analysis. - Chemical Engineering Journal 303: 627635.

[45] Xu, Z. S., Dai, X. H., Chai, X. L. (2018): Effect of different carbon sources on denitrification performance, microbial community structure and denitrification genes. Science of the Total Environment 634: 195-204.

[46] Yang, X., Wu, X., Hao, H. L., He, Z. L. (2008): Mechanisms and assessment of water eutrophication. - Journal of Zhejiang University Science B 9(3): 197-209.

[47] Ye, F., Ye, Y., Li, Y. (2011): Effect of C/N ratio on extracellular polymeric substances (EPS) and physicochemical properties of activated sludge flocs. - Journal of Hazardous Materials 188(1-3): 37-43.

[48] Yong, Z. J., Mjk, B., Ng, C. A., Sethupathi, S., Lim, J. W. (2017): A sequential treatment of intermediate tropical landfill leachate using a sequencing batch reactor (SBR) and coagulation. - Journal of Environmental Management 205: 244-252.

[49] Zeng, W., Li, L., Yang, Y. Y., Zhang, Y., Wang, S. Y. (2010): Short-cut nitrification and denitrification in $\mathrm{A}^{2} \mathrm{O}$ process treating domestic wastewater. - China Environmental Science 30(5): 625-632 (in Chinese).

[50] Zhang, H. F., Wang, Z. P., Zhang, L. H., Song, L. F. (2014): Impact of sludge cation distribution pattern on its filterability in membrane bioreactor. - Bioresource Technology 171: 16-21.

[51] Zhang, L., Zheng, P., Tang, C., Jin, R. (2008): Anaerobic ammonium oxidation for treatment of ammonium-rich wastewaters. - Journal of Zhejiang University Science B 9(5): 426-426.

[52] Zhang, M., Zhang, Y., Huang, P. L., He, C. D., Peng, Y. Z., Wu, J. (2017): Migration and transformation and utilization of organic matter in $\mathrm{A}^{2} / \mathrm{O}-\mathrm{MBBR}$ denitrifying phosphorus removal process. - China Environmental Science 37(11): 4132-4139 (in Chinese).

[53] Zhang, W. J., Yang, P., Xiao, P., Xu, S. W., Liu, Y. Y., Liu, F., Wang, D. S. (2015): Dynamic variation in physicochemical properties of activated sludge floc from different wwtps and its influence on sludge dewaterability and settleability. - Colloids and Surfaces A: Physicochemical and Engineering Aspects 467: 124-134.

[54] Zheng, Y. M., Yu, H. Q. (2007): Determination of the pore size distribution and porosity of aerobic granules using size-exclusion chromatograph. - Water Research 41(1): 39-46.

[55] Zhu, S., Chen, S. (2001): Effects of organic carbon on nitrification rate in fixed film biofilters. - Aquacultural Engineering 25(1): 1-11.

[56] Zhu, Z., Chang, L., Deng, D. (2014): Regulation of mixture liquid reflux ratio for effect of an improved $\mathrm{A}^{2} \mathrm{O}$ process. - Chinese Journal of Environmental Engineering 8(11): 4762-4766 (in Chinese). 